\title{
An Explorative Study for Laundry Mobile Application
}

\author{
Laundry Process Change
}

\author{
Doaa M. Bamasoud*, Asma M. Alqahtani, Eman A. Aljdea, Reem A. Alshomrani, Maha S. Alshahrani, Zohoor A. \\ Alghamdi, Ameerah M. Alghamdi, Shahd F. Almaawi, Asrar D. Alshahrani \\ Computer Science Department \\ Faculty of Computers \& Information Technology \\ University of Bisha, Asir, Saudi Arabia
}

\begin{abstract}
With the current rapid development of technology, many services need redesigning in order to keep up with customer demands. Therefore, organizations nowadays resort to redesigning services and business processes in order to maintain their competitiveness and success. With the recent advances in smartphone capabilities, and their growing penetration rate among individuals, organizations intend to take advantage of these devices by designing mobile applications to help evolve their business. The laundry business is one sector which has great potential for further development. Turning the ordinary routine of laundry into a service obtainable through a mobile application will contribute to reducing the burden of laundry tasks on individuals. This paper reviews the relevant literature and has design an instrument which investigates an individual's need for such mobile applications.
\end{abstract}

Keywords-Business process change; smartphones; mobile application; laundry

\section{INTRODUCTION}

Through the fast-paced evolution of information technology, and the modern style of living, people face dilemmas when finding sufficient time to do home duties, such as laundry, cleaning and cooking. With the advent of smartphones over the past years, and with their enhanced capabilities and growing penetration rates among individuals, organizations intend to take advantage of these devices for developing mobile applications which evolve and market their business services and goods [1]-[3]. While laundry is a daily need for everyone, it is at the same time a burdening and timeconsuming home duty. Consequently, developing a mobile application for bringing laundry services to a customer's doorstep will be effective and beneficial for both customers and service providers [4]. Through browsing literature, it can be determined that research seldom investigates the laundry sectors, and the redesigning of its business processes, through providing services online through mobile applications. Therefore, this research has been conducted in order to reinforce this area of knowledge. This paper has been structured into four main parts. The first section is an introduction, which introduces the topic, the research problem, and the research's significance. The second section presents the research's theoretical background, through a review of related literature. After that the research and data collection methodologies explain research methods, data collection procedures are undertaken, and the research's results are reported. Finally, a discussion and conclusion section presents the study's results.

\section{A. Research Problem}

People nowadays do not have sufficient time to complete home duties after work [4]. The development of information technology and mobile technologies has led to the development of electronic business (E-business), and has extended such business's competitive advantages [2]-[4]. Organizations intend to redesign their ordinary processes, and to change their business processes, in order to remain competitive, to obtain success, and to keep up with technology innovations [5], [6]. Therefore many business sectors have developed mobile applications designed to market their business services and goods [1], [3], [7].

\section{B. Research Significance}

One business sector which has not yet gained interest in research is the laundry business sector. As is commonly known, laundry is both a daily requirement for everyone, and a very burdensome task and time-consuming home duty. Therefore, developing a mobile application for bringing a laundry service to a customer's doorstep will be effective and beneficial for both the customer and the service provider [4], [8]. Research has seldom investigated the laundry sector, and its business process redesign through providing services online through mobile applications. Therefore, this research has been conducted in order to reinforce this area of knowledge.

\section{THEORETICAL BACKGROUND}

\section{A. Business Process Change}

The currently rapid change and growth of technology has revolutionized interactions between customers and business providers. Consequently, organizational changes have been motivated by exterior innovations, rather than by the internal factors of organizations. In [9], [10], the authors emphasized that organizations which decline to adopt innovative changes and advancements can be subsequently left behind. Therefore, organizations which have attempted business process changes are likely to achieve spectacular performance improvements and attain competitive advantages [9], [11]. For the time being, organizations must face recent technology developments, and must determine how to adapt to these changes [3]. 
In [6], the authors defined business process change as being the "methodological process that uses information technology to radically overhaul business processes, and thereby attain major business goals". Therefore, the goal of process change serves to maintain competitiveness and maximize organization benefits [9]. The employment of IT in any business plays a key role in changing organizational business processes and achieving success [5]. In [3] the author stated that mobile applications are valued by mobile users, and therefore mobile applications should be paid full attention. Additionally, it is notable that laundry is substantially important for everyone. However, literature has seldom covered the relationship between laundry, and the services that can be provided to customers via mobile applications.

\section{B. Impact of Technology}

People have started to use technology to serve themselves. Technology has invaded all aspects of our lives and has become substantial for everyone [12]. Therefore technology has greatly influenced people's lifestyles. Presently, great progress has been witnessed in smartphone technology, and smartphones are no longer just a means of voice communication. Rather, they provide various capabilities which help transform traditional services into electronic ones. With the rapid development of the internet and mobile technologies, these technologies have led to the development of mobile business, which is becoming increasingly innovative and diverse [2], [4].

\section{Laundry Services}

The evolution of a technology-focused life has helped solve most problems faced by individuals and has harnessed technology to help serve them and accomplish their goals [3], [4], [5]. In [5], the researcher emphasized the importance of service innovations to customers, by including an addition to the current service mix, or by changing the existing services offered. Laundry is a daily and time-consuming home duty. However, research has seldom investigated the laundry sector, and the means through which its business processes have been redesigned via digital applications. Developing a mobile application for bringing laundry services to a customer's doorstep will be effective and beneficial for both customers and services provider [4].

\section{METHODOLOGY}

\section{A. Instrument Development and Data Collection}

The survey instrument has been developed based through prior literature, refer to Fig. 1. In this particular case, the research has been collected through web-based surveys. The targeted respondents have been from different age ranges, and both genders. The instrument has been divided into two sections, as presented in Table I. The first section includes the demographic details of respondents, including their age, gender, marital status, employment, place of living, monthly income, whether or not the respondents possess smartphones, and what operating systems their smartphones use. The second section is divided into six constructs. The first of these constructs relates to perceived usefulness. This construct is designed to measure the degree to which a person believes that using a proposed mobile application will enhance the process of doing their laundry. The second construct relates to the perceived ease of use, which measures the degree to which a person believes that using a mobile application for laundry would minimize their expended efforts. The third construct relates to behavioral intention towards using a laundry mobile application, measuring the user's intention to use a laundry mobile application. The fourth construct involves redesigning the original laundry routine, which concerns measuring the degree to which a person believes using a proposed mobile app would change their ordinary laundry routine. The service's fifth construct concerns the user's personal opinion about services included within the proposed mobile application. The last construct is that of user satisfaction, which measures the user's satisfaction with services provided through the laundry mobile application.

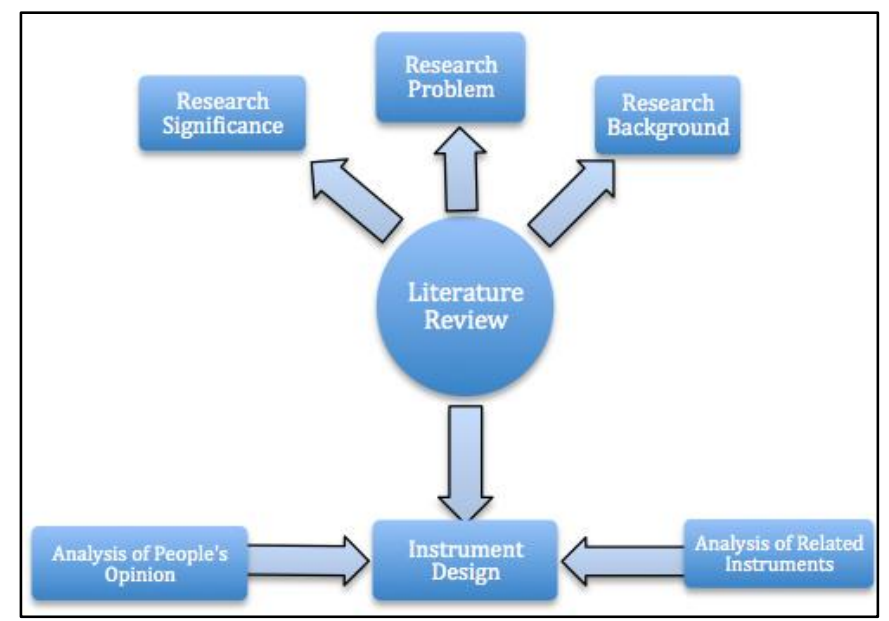

Fig. 1. Research methodology.

To ensure the developed instrument's clarity and content validity, experts must validate it [13]. In this study, three experts have validated the instrument. A 5-point Likert-type scale has been used, with a scale ranging from 1 (strongly disagree) to 5 (strongly agree). Table I describes the developed instrument.

TABLE I. SURVEY INSTRUMENT

\begin{tabular}{|l|l|}
\hline Classification & Survey Items \\
\hline \multirow{2}{*}{ Gender } & Male \\
& Female \\
\hline \multirow{3}{*}{ Marital Status } & Less than 18 years \\
& $\begin{array}{l}\text { 25 years to 25 years } \\
\text { More than 35 years }\end{array}$ \\
\hline \multirow{2}{*}{ Living } & Single \\
& Married \\
\hline \multirow{3}{*}{ Employment } & Alone \\
& With Family \\
& With Friends \\
\hline \multirow{3}{*}{ Monthly Income } & Student \\
& Employed \\
& Unemployed \\
\hline Possesses & Less than 3000 S.R \\
& 3000 S.R to 5000 S.R \\
& More than 10000 S.R \\
\hline
\end{tabular}




\begin{tabular}{|c|c|}
\hline Smartphone & No \\
\hline $\begin{array}{l}\text { Smartphone } \\
\text { Operating System }\end{array}$ & $\begin{array}{l}\text { iOS } \\
\text { Android }\end{array}$ \\
\hline $\begin{array}{l}\text { Perceived } \\
\text { Usefulness } \\
\text { Construct }\end{array}$ & $\begin{array}{l}\text { The degree to which the Laundry mobile application } \\
\text { will enhance the effectiveness of clients' laundry. } \\
\text { The laundry mobile application will facilitate the } \\
\text { laundry work of clients. } \\
\text { The laundry mobile application will increase client } \\
\text { productivity. } \\
\text { The laundry mobile application will be useful for } \\
\text { clients. }\end{array}$ \\
\hline $\begin{array}{l}\text { Perceived Ease of } \\
\text { Use } \\
\text { Construct }\end{array}$ & $\begin{array}{l}\text { I can easily learn how to use the Laundry mobile } \\
\text { application. } \\
\text { I can easily become a proficient in using the Laundry } \\
\text { mobile application. } \\
\text { I can use the Laundry mobile application very well if I } \\
\text { use it for enough time. } \\
\text { The laundry mobile application will make my laundry } \\
\text { process easier. } \\
\text { The use of the Laundry mobile application will not } \\
\text { require excessive effort. }\end{array}$ \\
\hline $\begin{array}{l}\text { Usage Behavior } \\
\text { Intention } \\
\text { Construct }\end{array}$ & $\begin{array}{l}\text { I plan to use the Laundry mobile application very } \\
\text { often. } \\
\text { I do not intend to take full advantage of the Laundry } \\
\text { mobile application. } \\
\text { I need to have a mobile app for laundry services. } \\
\text { I will strongly recommend others to use a Laundry } \\
\text { mobile application. }\end{array}$ \\
\hline $\begin{array}{l}\text { Redesigning } \\
\text { Ordinary Laundry } \\
\text { Routine Construct }\end{array}$ & $\begin{array}{l}\text { Using a Laundry mobile application is likely to } \\
\text { contribute to the success of changing my ordinary } \\
\text { laundry routine. } \\
\text { The Laundry mobile application will be useful in } \\
\text { identifying the process of redesigning the ordinary } \\
\text { laundry process. } \\
\text { The laundry mobile application will facilitate } \\
\text { identifying new opportunities for improvement. }\end{array}$ \\
\hline $\begin{array}{l}\text { Service Desired } \\
\text { Construct }\end{array}$ & $\begin{array}{l}\text { Do you support a partnership between the application } \\
\text { and the laundry shops spread throughout the region? } \\
\text { Do you prefer having a chat box with the person who } \\
\text { does the service? } \\
\text { Do you encourage the addition of an electronic } \\
\text { payment service? }\end{array}$ \\
\hline $\begin{array}{l}\text { User's Satisfaction } \\
\text { Construct }\end{array}$ & $\begin{array}{l}\text { Do you support having an urgent laundry service? } \\
\text { Would you like to have your clothes returned in more } \\
\text { private bags? } \\
\text { Do you support notifying clients when requests are } \\
\text { completed? } \\
\text { Do you support evaluating the service after } \\
\text { completion? } \\
\text { Do you support having separated laundry for clients, if } \\
\text { desired? }\end{array}$ \\
\hline
\end{tabular}

\section{B. Data Analysis}

IBM SPSS 14 statistical software has been used to carry out the statistical analysis. The descriptive statistics of the collected data and the reliability test were assessed through SPSS. A total of 70 successful responses were used in the analysis. The collected data has been examined for missing data and for respondents' test bias. A description of the sample has been provided in Table II.
TABLE II. SAMPLE DESCRIPTION

\begin{tabular}{|c|c|c|c|}
\hline & Label & $\begin{array}{l}\text { Frequency } \\
(\mathbf{N}=70)\end{array}$ & Percentage (100\%) \\
\hline Gender & $\begin{array}{l}\text { Male } \\
\text { Female }\end{array}$ & $\begin{array}{l}22 \\
48\end{array}$ & $\begin{array}{l}31.43 \% \\
68.57 \%\end{array}$ \\
\hline Age & $\begin{array}{l}\text { Less } 18 \text { years } \\
18 \text { - } 25 \text { years } \\
25 \text { - } 35 \text { years } \\
\text { More } 35 \text { years }\end{array}$ & $\begin{array}{l}8 \\
30 \\
13 \\
19\end{array}$ & $\begin{array}{l}11.43 \% \\
42.86 \% \\
18.57 \% \\
27.14 \%\end{array}$ \\
\hline $\begin{array}{l}\text { Marital } \\
\text { Status }\end{array}$ & $\begin{array}{l}\text { Single } \\
\text { Married }\end{array}$ & $\begin{array}{l}38 \\
32\end{array}$ & $\begin{array}{l}54.29 \% \\
45.71 \%\end{array}$ \\
\hline Living & $\begin{array}{l}\text { Alone } \\
\text { With Family } \\
\text { With Friends }\end{array}$ & $\begin{array}{l}4 \\
66 \\
0\end{array}$ & $\begin{array}{l}5.71 \% \\
94.29 \% \\
0 \%\end{array}$ \\
\hline Employment & $\begin{array}{l}\text { Student } \\
\text { Employed } \\
\text { Unemployed }\end{array}$ & $\begin{array}{l}33 \\
30 \\
7\end{array}$ & $\begin{array}{l}47.14 \% \\
42.86 \% \\
10 \%\end{array}$ \\
\hline $\begin{array}{l}\text { Monthly } \\
\text { Income }\end{array}$ & $\begin{array}{l}\text { Less } 3000 \text { S. R } \\
3000-5000 \text { S. R } \\
5000-10000 \text { S.R } \\
\text { More } 10000 \text { S. R }\end{array}$ & $\begin{array}{l}38 \\
4 \\
8 \\
20\end{array}$ & $\begin{array}{l}54.29 \% \\
5.71 \% \\
11.43 \% \\
28.57 \%\end{array}$ \\
\hline $\begin{array}{l}\text { Possesses } \\
\text { Smartphone }\end{array}$ & $\begin{array}{l}\text { Yes } \\
\text { No }\end{array}$ & $\begin{array}{l}70 \\
0\end{array}$ & $\begin{array}{l}100 \% \\
0 \%\end{array}$ \\
\hline $\begin{array}{l}\text { Smartphone } \\
\text { Operating } \\
\text { System }\end{array}$ & $\begin{array}{l}\text { IOS } \\
\text { Android }\end{array}$ & $\begin{array}{l}44 \\
26\end{array}$ & $\begin{array}{l}62.86 \% \\
37.14 \%\end{array}$ \\
\hline
\end{tabular}

TABLE III. SURVEY RESULTS

\begin{tabular}{|c|c|c|c|}
\hline Construct & Measure & $\begin{array}{l}\text { Cronbach's } \\
\text { Alpha }\end{array}$ & $\begin{array}{l}\text { Cronbach's Alpha } \\
\text { if Item is Deleted }\end{array}$ \\
\hline $\begin{array}{l}\text { Perceived } \\
\text { Usefulness }\end{array}$ & $\begin{array}{l}\text { PU1 } \\
\text { PU2 } \\
\text { PU3 } \\
\text { PU4 }\end{array}$ & .866 & $\begin{array}{l}.850 \\
.828 \\
.797 \\
.844\end{array}$ \\
\hline $\begin{array}{l}\text { Perceived Ease } \\
\text { of Use }\end{array}$ & $\begin{array}{l}\text { EoU1 } \\
\text { EoU2 } \\
\text { EoU3 } \\
\text { EoU4 } \\
\text { EoU5 }\end{array}$ & .884 & $\begin{array}{l}.858 \\
.861 \\
.843 \\
.845 \\
.885\end{array}$ \\
\hline $\begin{array}{l}\text { Usage Behavior } \\
\text { Intention }\end{array}$ & $\begin{array}{l}\mathrm{BI} 1 \\
\mathrm{BI} 2 \\
\mathrm{BI} 3 \\
\mathrm{BI} 4\end{array}$ & .722 & $\begin{array}{l}.562 \\
.866 \\
.595 \\
.550\end{array}$ \\
\hline $\begin{array}{l}\text { Redesigned } \\
\text { Original } \\
\text { Laundry } \\
\text { Routine }\end{array}$ & $\begin{array}{l}\text { RedPro1 } \\
\text { RedPro2 } \\
\text { RedPro3 }\end{array}$ & .778 & $\begin{array}{l}.705 \\
.669 \\
.728\end{array}$ \\
\hline $\begin{array}{l}\text { Services } \\
\text { Desired }\end{array}$ & $\begin{array}{l}\text { Dsrdsrvc1 } \\
\text { Dsrdsrvc2 } \\
\text { Dsrdsrvc3 }\end{array}$ & .685 & $\begin{array}{l}.606 \\
.732 \\
.419\end{array}$ \\
\hline $\begin{array}{l}\text { User's } \\
\text { Satisfaction }\end{array}$ & $\begin{array}{l}\text { Usrsat1 } \\
\text { Usrsat2 } \\
\text { Usrsat3 } \\
\text { Usrsat4 } \\
\text { Usrsat5 }\end{array}$ & .744 & $\begin{array}{l}.655 \\
.681 \\
.700 \\
.701 \\
.751\end{array}$ \\
\hline
\end{tabular}

Out of 70 respondents, 48 or $68.57 \%$ were females, and 22 or $31.43 \%$ were males. $11.43 \%$ of the respondents were younger than 18 years, while $42.86 \%$ were aged between 18 and 25 years, $18.57 \%$ were between the ages of 25 and 35 years, and $27.14 \%$ were over 35 years. $54.29 \%$ of the respondents were single, and $45.71 \%$ are married. $5.71 \%$ of the 
respondents lived alone, while $94.29 \%$ lived with their families, and none lived with their friends. $47.14 \%$ of the respondents were students, $42.86 \%$ were employed and $10 \%$ were unemployed. $54.29 \%$ of respondents had a monthly income of less than $3,000 \mathrm{SR}$, while $5.71 \%$ of them had a monthly income of between 3,000 and 5,000 SR, and $11.43 \%$ had a monthly income of 5,000 to 10,000 SR. $28.57 \%$ of respondents had a monthly income which exceeded 10,000 SR. All respondents possessed smartphones, with $62.86 \%$ owning iOS smartphones, and $37.14 \%$ owning android smartphones.

The authors used SPSS14 to validate the developed instrument, and deployed a scale reliability test for the proposed instrument measures. An internal reliability analysis has helped assess goodness of fit [14]. The most popular assessment of inter-item consistency reliability is the Cronbach's alpha, and accordingly it has been employed for the pilot data. In [15] the researchers stated that a Cronbach's alpha value of at least 0.5 is considered good for measures.

Table III has shown the statistical results of reliability. The overall Cronbach's alpha value for the perceived usefulness construct is 0.866 , which is considered a high value. Within the perceived ease of use construct, the overall Cronbach's alpha value is 0.884 , which is also considered to be a high value. Furthermore, the overall Cronbach's alpha of the usage behavior intention construct is 0.722 , which is considered a good value. The redesign original laundry routine construct has an overall Cronbach's alpha value of 0.778 , which is considered to be a high value. The services' desired construct has an overall Cronbach's alpha value of 0.685 , which is considered a good value. Finally, the user's satisfaction construct has an overall Cronbach's alpha value of 0.744 , which is considered a high value. By referring to the results in Table III, the Cronbach's alpha values for all six constructs are considered good. Therefore, there is no need to exclude and delete items of the constructs to raise the Cronbach's alpha of those constructs. Consequently, the researchers retain all items and measures of constructs.

\section{DISCUSSION AND CONCLUSIONS}

This paper has highlighted change of business process, and its importance in meeting the requirements of individuals regarding technological advancements and innovations in the laundry sector. Furthermore, the paper has highlighted the current importance of smartphones, and the electronic services which can be offered through mobile applications and their contributions to redesigning and changing ordinary processes of business sectors. The authors emphasized meeting the needs of individuals, by exploiting and utilizing the smartphones, and by providing electronic services using mobile applications. Therefore, this paper aims to draw attention to the importance of how mobile applications can facilitate the changing of business processes within business sectors.

\section{FUTURE WORK}

Future work will focus on conducting a main study. Research has been planned in order to further explore the theoretical and practical aspects of how smartphones' mobile applications for the laundry sector can help ease the burden laundry places on people and can deliver services wherever they are. Moreover, the research plans to explore the influence of such mobile applications particularly in Saudi Arabia.

\section{ACKNOWLEDGMENT}

The authors Asma M. Alqahtani, Eman A. Aljdea, Reem A. Alshomrani, Maha S. Alshahrani, Zohoor A. Alghamdi, Ameerah M. Alghamdi, Shahd F. Almaawi, and Asrar D. Alshahrani would like to express their deep gratitude to: 1) University of Bisha; and 2) Ministry of Education Kingdom of Saudi Arabia for their support in pursuing their undergraduate study.

\section{REFERENCES}

[1] Liébana-Cabanillas, F. Muñoz-Leiva and F.- Sánchez-Fernández, J., “A global approach to the analysis of user behavior in mobile payment systems in the new electronic environment," Service Business, vol. 12, 2018, no. 1, pp. 25-64.

[2] Ramakrishna, V. and Dey, K., "Mobile application and user analytics. In mobile application development, usability, and security," 2017, pp. 231-259.

[3] Rupnik, R. "Mobile applications development methodology," handbook of research in mobile business: technical, methodological and social perspectives, 2009, pp. 160-172.

[4] Priambodo, B. and Ani, N., "M-Laundry advertisement system utilizing location based service," international journal of advanced research in computer science and software engineering, vol. 6,2016, no. 6, pp.5963.

[5] Ye, H. and Kankanhalli, A., "User service innovation on mobile phone platforms : investigating impacts of lead userness, Toolkit Support, and Design Autonomy," MIS quarterly, vol. 42, 2018, no. 1, pp. 1-47.

[6] Grover, V. Teng, J. T. C. and Fiedler, K. D., "Information technology enabled business process redesign: an integrated planning framework,"Omega,vol. 21, 1993, no. 4, pp.433-447.

[7] Baloh, P. and Trkman, P.,'Influence of internet and information technology on work and human resource management," Informing Science, vol. 6, 2003, pp. 498-505.

[8] Jamgade, A., "Online laundry service," international journal of scientific research in computer science. Engineering and Information Technology, vol. 2, 2017, no. 1, pp. 195-197.

[9] Kasemsap, K., "The role of business process reengineering in the modern business world," In I. management association (Ed.). Project management: concepts, methodologies, tools, and applications, 2016, pp. 1802-1829.

[10] Skelsey, D., "Why do people in business resist change?," Project Laneway. Available on: http://archive.is/jzSul (2003). Accessed 9 January 2018

[11] Grover, V. Teng, J., Segars, A. and H.- Fiedler, K., "The influence of information technology diffusion and business process change on perceived productivity: The IS executive's perspective," Information and management, 1998, pp. 141-159.

[12] Zulkefly S. N. and Baharudin R., "Mobile phone use amongst students in a university in Malaysia: Its correlates and relationship to psychological health," European Journal of scientific research, vol. 27, 2009, no. 2, pp. 206-218.

[13] Boudreau, M. C. Gefen, D. and Straub, D. W., "Validation in information systems research: A state-of-the-art assessment," MIS quarterly, vol. 25, 2001, no. 1, pp. 1-16.

[14] Cavana R. Delahaye B. and Sekaran U., "Applied business research: qualitative and quantitative methods," Queensland: John Wiley and Sons, Australia, 2001.

[15] Schmidt F. and L.-Hunter J., "General mental ability in the world of work: Occupational attainment and job performance," Journal of personality and social psychology, vol.86, 2004, no. 1, pp. 162-173. 